\title{
FAKTOR-FAKTOR YANG MEMPENGARUHI HARGA DAN KETERSEDIAAN BERAS DI TINGKAT NASIONAL
}

\author{
Widodo \\ (Program Pascasarjana, Fakultas Pertanian Universitas Gadjah Mada)
}

\begin{abstract}
The objectives of this study were: (1) to understand the development of domestic rice prices at the national level, (2) to identify factors that influence the domestic rice prices at the national level, and (3) to determine the factors that affect the availability of rice at the national level. The data used in this research was secondary data obtained from the BPS, BULOG, and FAO statistics. The data obtained were systematically recording in the form of a time series data since 1979 until 2008 at the national level. The model used in this research is simple regression equation or the Ordinary Least Square (OLS). This model was used to identify trends and the factors affecting the price and availability of rice nationwide. Regression equations estimated to test the functionality of $R^{2}$, the F-test, $t$-test, and D-W.The results of this study indicate: (1) the rate of growth of retail rice prices at the national level has increased in the positive trend, (2) the domestic rice prices at the national level is influenced by the base price of grain and world rice prices, and (3) the availability of long-term national from the year 1979-2008 rice prices was influenced by domestic supply, exchange rate farmers, the harvested area, and the availability of rice before and after the moneter crisis. The availability of rice in the short term before and after the crisis were influenced significantly by harvested area, at the time of pre-crisis (1979-1997) and by domestic supply, farmers exchange rate, and the harvested area, on the time after the crisis (1997-2008).
\end{abstract}

Key words: domestic rice prices, rice availability

\begin{abstract}
Abstrak: Penelitian ini bertujuan untuk: (1) mengetahui perkembangan harga beras eceran di tingkat nasional, (2) mengetahui faktor-faktor yang mempengaruhi harga beras domestik di tingkat nasional, dan (3) mengetahui faktor-faktor yang mempengaruhi ketersediaan beras di tingkat nasional. Data yang digunakan dalam penelitian adalah data sekunder yang bersumber dari BPS, BULOG, dan Statistik FAO. Data yang diperoleh merupakan pencatatan yang sistematis berupa data runtut waktu (time series) nasional dari tahun 1979-2008. Model yang digunakan dalam penelitian ini adalah persamaan regresi sederhana atau Ordinary Least Square (OLS). Model ini digunakan untuk mengetahui perkembangan dan factor-faktor yang mempengaruhi harga serta ketersediaan beras secara nasional. Hasil estimasi fungsi persamaan regresi dilakukan uji $\mathrm{R}^{2}$, F-test, t-test, dan D-W. Hasil analisis dalam penelitian ini memperlihatkan (1) laju perkembangan harga beras eceran di tingkat nasional mengalami kecenderungan meningkat secara positif, (2) harga beras domestik di tingkat nasional dipengaruhi oleh harga dasar gabah dan harga beras dunia, dan (3) ketersediaan beras jangka panjang di tingkat nasional dari tahun 1979-2008 dipengaruhi oleh pengadaan dalam negeri, nilai tukar petani, dan luas panen serta ketersediaan beras sebelum dan sesudah krisis. Ketersediaan beras jangka pendek sebelum dan setelah krisis dipengaruhi secara signifikan oleh faktor-faktor penentu yang ditetapkan. Pada saat sebelum krisis (1979-1997), luas panen mempengaruhi secara signifikan dan pada saat sesudah krisis (1997-2008), pengadaan dalam negeri, nilai tukar petani, dan luas panen mempengaruhi secara signifikan.
\end{abstract}

Kata kunci: harga beras eceran, ketersediaan beras 


\section{PENDAHULUAN}

Beras merupakan komoditas yang strategis bagi Bangsa Indonesia. Secara historis komoditas beras tidak hanya sebagai komoditas ekonomi melainkan juga komoditas sosial-politik. Hal ini tampak sejak Pemerintah Hindia-Belanda, beras menjadi sumber kalori utama bagi para gerilyawan. Beras juga merupakan satu-satunya komoditas yang mengawal pemulihan kepercayaan masyarakat terhadap Pemerintahan Orde Baru. Kegagalan dalam penyediaan pangan utama akan bisa menimbulkan dampak sosial-politik yang sangat mahal (Pranadji, 2003).

Faktor yang menyebabkan prediksi impor beras sangat tinggi menurut Krisnamurti (Kompas, 2003) adalah: (1) keterlambatan panen musim rendeng (juga akan berakibat pada keterlambatan pada musim tanam gadu), sehingga bisa memperparah produksi beras dalam negeri, (2) insentif kenaikan harga dasar gabah diperkirakan belum mampu menaikkan produksi, dan (3) kemungkinan dampak El Nino tahun 2003 lebih besar dibanding tahun 2002. Kebijakan menaikkan harga dasar gabah dinilai tidak memberikan insentif bagi petani yang melakukan produksi karena pada saat yang bersamaan harga-harga barang lain mengalami kenaikan. Panen musim rendeng menyumbang $60-65 \%$ produksi padi total tiap tahunnya (Sawit, 2000).

Sejak pertengahan 1997, Indonesia dilanda krisis moneter yang kemudian berlanjut pada krisis pangan karena kemarau panjang El Nino. Hal ini membuat 34 produksi pangan khususnya beras dalam negeri merosot tajam pada tahun 1997 dan 1998, sehingga dengan sedikitnya jumlah beras yang beredar di masyarakat berakibat menaikkan harga beras.

Pada tahun 1998 harga beras dunia lebih rendah daripada harga domestik karena terjadi oversupply, sehingga importir swasta, yang pada dasarnya ingin memperoleh keuntungan sebesar-besarnya, melakukan impor dalam jumlah besar dan menjualnya dengan harga lebih murah di dalam negeri. Dengan telah bergesernya selera konsumen dalam memilih produk pangan impor, yang dianggap memiliki kualitas lebih baik serta ditunjang dengan harga yang lebih murah dibanding beras domestik, maka konsumen memilih untuk mengkonsumsi beras impor sehingga beras domestik yang telah menumpuk di gudang BULOG dan panen raya yang cukup berhasil semakin menekan petani karena harga gabah yang sangat rendah.

Sampai dengan awal tahun 1999, 'banjir' beras impor di dalam negeri masih banyak terjadi, bahkan isu beras oplosan yaitu beras campuran impor dan dalam negeri serta beras yang masuk secara illegal hangat dibicarakan. BULOG memutuskan untuk membeli gabah langsung dari petani dan bukan membeli beras seperti yang dilakukan selama ini. Kebijakan ini dianggap lebih efektif mengangkat harga gabah karena pembelian beras tidak akan selalu diikuti dengan kenaikan harga gabah oleh karena pengaruh beras impor. Pemerintah hanya membeli gabah di wilayah produsen utama padi di samping tentunya BULOG membeli beras di pasar bila persediaan dalam negeri tidak mencukupi dan sebaliknya, pemerintah tidak melakukan impor beras apabila persediaan dalam negeri mencukupi (Sawit, 2000).

Dari uraian di atas, maka dalam penelitian ini akan dikaji terhadap perkembangan harga beras selama ini. Faktorfaktor yang mempengaruhi harga beras dan ketersediaan beras di tingkat nasional menjadi kajian selanjutnya dalam penelitian ini dengan harapan para pelaku perberasan dapat menyusun suatu rancangan kegiatan dalam pengelolaan perberasan baik di tingkat rumah tangga maupun nasional.

\section{METODE PENELITIAN}

Metode dasar yang digunakan dalam penelitian ini adalah metode deskriptif analitis yaitu suatu metode yang digunakan untuk mengumpulkan, mengolah, menganalisis, dan menyajikan data secara sistematik sehingga lebih mudah untuk difahami dan disimpulkan. Setelah itu dilanjutkan pada taraf inferensial yaitu pengambilan kesimpulan dari hasil analisis yang diperoleh. Jenis data yang digunakan dalam penelitian adalah data sekunder yang bersumber dari BPS, BULOG dan Statistik FAO. Data yang diperoleh merupakan pencatatan yang sistematis berupa data runtut waktu (time series) secara nasional selama 30 tahun terakhir dari tahun 1979-2008. 


\section{Analisis perkembangan harga beras eceran di tingkat nasional}

Dalam penelitian ini, untuk mengukur trend harga beras eceran di tingkat nasional digunakan metode trend analysis atau regresi sederhana dengan model estimasi berikut:

$$
\mathrm{HB}_{\mathrm{t}}=\alpha+\beta \mathrm{t}_{\mathrm{i}}+\mu_{\mathrm{i}}
$$

$$
\begin{aligned}
& \text { di mana: } \\
& \mathrm{HB}_{\mathrm{t}}=\text { Harga Beras Eceran pada waktu } \mathrm{t} \\
& \mathrm{t}_{\mathrm{i}}=\text { tahun ke- } \mathrm{i} \\
& \alpha=\text { konstanta/intercept } \\
& \beta=\text { trend } \text { harga beras eceran }
\end{aligned}
$$

\section{Analisis faktor - faktor yang mempengaruhi harga beras domestik di tingkat nasional}

Model untuk mengetahui faktor-faktor yang mempengaruhi harga beras eceran di tingkat nasional sebagai berikut:

$\mathrm{HB}_{\mathrm{t}}=b_{0}+b_{1} \mathrm{TPD}_{\mathrm{t}}+b_{2} \mathrm{HDG}_{\mathrm{t}}+b_{3} \mathrm{NTP}_{\mathrm{t}}+b_{4}$ $\mathrm{HBD}_{\mathrm{t}}+b_{5} \mathrm{IB}_{\mathrm{t}}+b_{6} \mathrm{HJ}_{\mathrm{t}}+v_{\mathrm{t}}$

Untuk analisis regresi dari model tersebut digunakan transformasi model menjadi:

$\ln \mathrm{HB}_{\mathrm{t}}=\ln b_{0}+b_{1} \ln \mathrm{TPD}_{\mathrm{t}}+b_{2} \ln \mathrm{HDG}_{\mathrm{t}}+b_{3} \ln$ $\mathrm{NTP}_{\mathrm{t}}+b_{4} \ln \mathrm{HBD}_{\mathrm{t}}+b_{5} \ln \mathrm{IB}_{\mathrm{t}}+$

$$
b_{6} \operatorname{lnHJ}_{\mathrm{t}}+v_{\mathrm{t}}
$$

di mana:

$\mathrm{HB}=$ Harga Beras Domestik $(\mathrm{Rp} / \mathrm{kg})$

$\mathrm{TPD}=$ Total Produksi Padi (000 ton)

HDG = Harga Dasar Gabah (rupiah)

NTP = Indeks Nilai Tukar Petani

HBD = Harga Beras Dunia (US \$)

HJ = Harga Jagung (rupiah)

IB $=$ Impor Beras (000 ton)

\section{Analisis faktor - faktor yang mempengaruhi ketersediaan beras di tingkat nasional}

Untuk lebih mengetahui besarnya pengaruh masing-masing faktor terhadap ketersediaan beras nasional dapat digunakan analisis regresi sederhana dengan model $\mathrm{Q}_{\mathrm{t}}=\mathrm{f}\left(\mathrm{PD}_{\mathrm{t}}, \mathrm{NTP}_{\mathrm{t}}\right.$, $\left.\mathrm{KK}_{\mathrm{t}}, \mathrm{LP}_{\mathrm{t}}, \mathrm{RH}_{\mathrm{t}}, \mathrm{D}\right)$. Analisis dengan menggunakan model regresi linier sederhana ternyata memberikan hasil analisis yang kurang tepat sehingga digunakan model (Darwanto, 2005) sebagai berikut:
$\mathrm{Q}_{\mathrm{t}}=\mathrm{b}_{0} \mathrm{PD}_{\mathrm{t}}^{\mathrm{b} 1} \mathrm{NTP}_{\mathrm{t}}^{\mathrm{b} 2} \mathrm{KK}_{\mathrm{t}}^{\mathrm{b} 3} \mathrm{LP}_{\mathrm{t}}^{\mathrm{b} 4} \mathrm{RH}_{\mathrm{t}}^{\mathrm{b} 5} 3^{\mathrm{dD}}$.(4)

di mana:

$\mathrm{Q}_{\mathrm{t}}=$ Ketersediaan Beras di tahun ke-t $(000 \mathrm{t})$

$\mathrm{PD}_{\mathrm{t}}=$ Pengadaan Dalam Negeri pada tahun ke-t $(000 \mathrm{t})$

$\mathrm{NTP}_{\mathrm{t}}=$ Indeks Nilai Tukar Petani pada tahun ke-t

$\mathrm{KK}_{\mathrm{t}}=$ Tingkat Konsumsi per kapita pada tahun ke-t $(\mathrm{kg} / \mathrm{kap} / \mathrm{th})$

$\mathrm{LP}_{\mathrm{t}}=$ Luas Panen Padi di tahun ke-t (000 ha)

$\mathrm{RH}_{\mathrm{t}}=$ Rasio Harga Riil Domestik dan Internasional pada tahun ke-t

$\mathrm{D}=$ Dummy setelah krisis, $\mathrm{D}=0$ untuk sebelum krisis dan $\mathrm{D}=1$ untuk setelah krisis

$\mathrm{b}_{0}=$ konstanta $; \mathrm{b}_{1}, \mathrm{~b}_{2}, \mathrm{~b}_{3}, \mathrm{~b}_{4}, \mathrm{~b}_{5}=$ koefisien regresi

Untuk analisis regresi dari model tersebut digunakan transformasi model menjadi:

$$
\begin{aligned}
& \ln \mathrm{Q}_{\mathrm{t}}=\operatorname{lnb}_{0}+\mathrm{b}_{1} \quad \ln \mathrm{PD}_{\mathrm{t}}+\mathrm{b}_{2} \quad \operatorname{lnNTP}_{\mathrm{t}}+\mathrm{b}_{3} \\
& \operatorname{lnKK_{\mathrm {t}}}+\mathrm{b}_{4} \operatorname{lnL} \mathrm{P}_{\mathrm{t}}+\mathrm{b}_{5} \operatorname{lnR} \mathrm{H}_{\mathrm{t}}+\mathrm{dD}
\end{aligned}
$$

Untuk memperoleh gambaran empiris yang lebih rinci maka analisis regresi dengan model tersebut di atas dilakukan untuk tiga periode pengamatan yaitu periode sebelum krisis (1979-1998), periode setelah krisis (1998-2008) dan periode keseluruhan (19792008).

Fungsi dalam persamaan 3 dan 5 tersebut kemudian diestimasi menggunakan metode Ordinary Least Square (OLS) dengan uji $\mathrm{R}^{2}$, F-test, t-test, dan D-W. Data dianalisis dengan menggunakan Program Eviews (Widarjono, 2009).

\section{HASIL DAN PEMBAHASAN}

\section{Hasil analisis trend harga beras eceran di tingkast nasional}

Tabel 1. memperlihatkan hasil analisis trend yang menunjukkan pada harga beras eceran dalam persamaan linier diindikasikan dengan nilai $R^{2}$ dan $F$ yang tinggi. Nilai $R^{2}$ pada persamaan linier menunjukkan angka 0.697553 dengan nilai $F$ sebesar 853.3555. Secara grafis, kurva persamaan tersebut dapat dilihat pada Gambar 1. 
Widodo: Faktor-faktor Yang Mempengaruhi Harga Dan Ketersediaan ...

Tabel 1. Persamaan Trend Harga Beras Eceran

\begin{tabular}{ccccc}
\hline Trend & Persamaan & $\mathrm{R}^{2}$ & $\mathrm{~F}$ & $\mathrm{P}$ \\
\hline Linier & $\mathrm{HB}_{\mathrm{t}}=1636.739+4.280626(\mathrm{t})$ & 0.697553 & 853.3555 & 0.000000 \\
\hline
\end{tabular}

Sumber : Analisis data sekunder

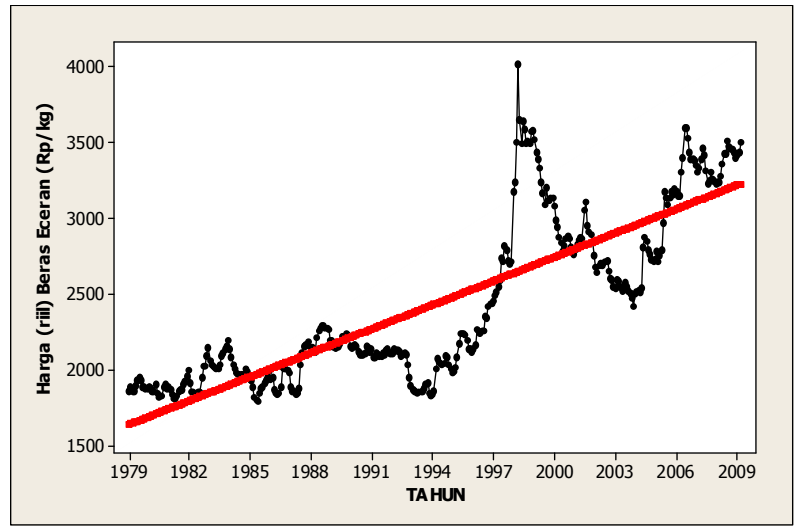

Sumber : BPS dan BULOG tahun 1979-2008

Gambar 1. Trend Harga Beras Eceran 1979-2008

Pada persamaan dalam Tabel 1. dan Gambar 1. memperlihatkan sebaran peubah harga beras eceran mengikuti trend line. Rachman (2005) menyatakan bahwa metode grafis ini sebagai salah satu cara yang mudah dan sederhana untuk mengetahui pola perilaku harga dan laju perubahan yang ada, dimana peubah harga sebagai aksis vertikal dan periode waktu sebagai aksis horisontal.

Perkembangan harga beras eceran di tingkat petani menunjukkan trend yang positif dan cenderung meningkat terus. Namun laju perkembangan ini tidak berarti bahwa petani padi di Indonesia semakin sejahtera karena kenaikkan harga tersebut. Hal ini tergantung pada dua hal yaitu pertama, perubahan hargaharga dari input-input yang dibutuhkan dalam produksi padi seperti pupuk, benih dan lainnya. Kedua, tingkat inflasi atau perubahan dari harga-harga dari kebutuhan pokok. Dengan kata lain, jika harga-harga dari input-input tersebut atau inflasi selama periode yang sama juga mengalami kenaikan dan dengan laju yang lebih tinggi daripada laju kenaikan harga jual, maka petani padi tetap mengalami kerugian.

\section{Hasil analisis faktor-faktor yang mempengaruhi harga beras domestik di tingkat nasional}

Pada Tabel 2. menunjukkan hasil analisis regresi Ordinary Least Square (OLS) terhadap faktor-faktor yang mempengaruhi harga beras domestik.

Dari Tabel 2. diatas dapat dilihat bahwa nilai $\mathrm{R}^{2}$ sebesar 0,513370 yang menunjukkan bahwa kontribusi pengaruh variabel-variabel bebas pada variabel terikat adalah sebesar $51,34 \%$. Nilai $F$ sebesar 3,868148 dengan probabilitas $0,008713<0,05$, menunjukkan secara bersama-sama variabel bebas memberikan pengaruh pada variabel terikat. Nilai D-W sebesar 1,772270 ada pada daerah dL $(0,926)$ sampai dU $(2,034)$. Daerah di mana tidak ada keputusan terkait dengan gejala autokorelasi.

Hasil analisis menunjukkan bahwa dari enam variabel bebas (total produksi padi, harga dasar gabah, indeks nilai tukar petani, harga beras dunia, harga jagung dan impor beras), dua diantaranya (harga dasar gabah dan harga beras dunia) ditemukan berpengaruh signifikan pada harga beras domestik. Hasil-hasil analisis dapat diuraikan sebagai berikut: 
Widodo: Faktor-faktor Yang Mempengaruhi Harga Dan Ketersediaan ...

Tabel 2. Hasil Analisis Faktor-faktor yang Mempengaruhi Harga Beras Domestik

\begin{tabular}{lccc}
\hline Variabel & Koefisien Regresi & \\
\hline Konstanta & $-0,012053$ & \\
& $-0,618112$ & \\
In Nilai Tukar Petani (NTP) & 0,181193 & ts \\
In Harga Dasar Gabah (HDG) & 0,710850 & \\
& 0,166213 & $*$ \\
ln Harga Beras Dunia (HBD) & 1,910962 & \\
& 0,123430 & $* *$ \\
In Total Produksi Padi (TPD) & 2,755737 & \\
& $-0,142547$ & ts \\
ln Harga Jagung ( HJ) & $-0,414110$ & \\
& 0,207981 & ts \\
In Impor Beras (IB) & 1,222490 & \\
R & 0,012715 & ts \\
Adjusted R & 1,373829 & \\
F (p) & 0,513370 & \\
D-W & 0,380653 & \\
\hline
\end{tabular}

\footnotetext{
Sumber : Analisis data sekunder tahun 1979-2008

Catatan:

*** = signifikan pada tingkat kepercayaan $1 \%$

** = signifikan pada tingkat kepercayaan 5\%

* = signifikan pada tingkat kepercayaan $10 \%$

ts = tidak sigbifikan

Angka cetak miring adalah nilai t-terhitung
}

Indeks nilai tukar petani (NTP), memiliki koefisien regresi 0,181193 dengan t-terhitung $0,710850 \quad(\mathrm{p}=0,4846>0,05)$. Membandingkan nilai t-terhitung dengan $\mathrm{t}$ tabel pada df $(n-1)=29$ dan $\alpha=0,05$; yaitu 2,045, maka t-terhitung $<\mathrm{t}$-tabel.

Dengan demikian, hipotesis $\mathrm{H}_{0}$ yang menyatakan tidak ada pengaruh indeks nilai tukar petani pada harga beras, diterima dan $\mathrm{Ha}$ yang menyatakan ada pengaruh indeks nilai tukar petani pada harga beras, ditolak. Artinya NTP tidak berpengaruh pada harga beras.

Harga dasar gabah (HDG), memiliki koefisien regresi sebesar 0,166213 dengan t-terhitung 1,910962 $(\mathrm{p}=0,0691<0,10)$. Membandingkan nilai t-terhitung dengan $t$ tabel pada df $(n-1)=29$ dan $\alpha=0,10$; yaitu 1,699 , maka t-terhitung $>\mathrm{t}$-tabel. Dengan demikian, hipotesis $\mathrm{H}_{0}$ yang menyatakan tidak ada pengaruh harga dasar gabah pada harga beras, ditolak dan Ha yang menyatakan ada pengaruh harga dasar gabah pada harga beras, diterima. Artinya harga dasar gabah berpengaruh pada harga beras. Kenaikan harga dasar gabah sebesar $1 \%$ akan diiringi dengan kenaikan harga beras sebesar $0,17 \%$.

Harga beras dunia (HBD), memiliki koefisien regresi sebesar 0.123430 dengan t-terhitung 2,755737 ( $\mathrm{p}=0.0115<0,05)$. Membandingkan nilai t-terhitung dengan $t$ tabel pada df $(\mathrm{n}-1)=29$ dan $\alpha=0,05$; yaitu 2,045, maka t-terhitung $>\mathrm{t}$-tabel. Dengan demikian, hipotesis $\mathrm{H}_{0}$ yang menyatakan tidak ada pengaruh harga beras dunia pada harga beras, 
ditolak dan Ha yang menyatakan ada pengaruh harga beras dunia pada harga beras, diterima. Artinya harga beras dunia berpengaruh pada harga beras domestik. Kenaikan harga beras dunia sebesar $1 \%$ akan diiringi kenaikan harga beras domestik sebesar $0,12 \%$. Total produksi padi (TPD), memiliki koefisien regresi sebesar $-0,142547$ dengan $\mathrm{t}$-terhitung $-0,414110(\mathrm{p}=$ $0,6828>0,05)$. Membandingkan nilai $t-$ terhitung dengan $\mathrm{t}$ tabel pada $\mathrm{df}(\mathrm{n}-1)=29$ dan $\alpha=0,05$; yaitu 2,045 , maka t-terhitung $<\mathrm{t}$ tabel. Dengan demikian, hipotesis $\mathrm{H}_{0}$ yang menyatakan tidak ada pengaruh total produksi padi pada harga beras, diterima dan Ha yang menyatakan ada pengaruh total produksi padi pada harga beras, ditolak. Artinya total produksi padi tidak berpengaruh pada harga beras. Tanda negatif menunjukkan bahwa total produksi padi berbanding terbalik dengan harga beras, pada saat produksi padi melimpah harga beras rendah.

Harga jagung (HJ), memiliki koefisien regresi sebesar 0.207981 dengan t-terhitung $1,222490(\mathrm{p}=0,2345<0,10)$. Membandingkan nilai $\mathrm{t}$-terhitung dengan $\mathrm{t}$ tabel pada df $(\mathrm{n}-1)=$ 29 dan $\alpha=0,10$; yaitu 1,699 , maka t-terhitung $<\mathrm{t}$-tabel. Dengan demikian, hipotesis $\mathrm{H}_{0}$ yang menyatakan tidak ada pengaruh harga jagung pada harga beras, diterima dan $\mathrm{Ha}$ yang menyatakan ada pengaruh harga jagung pada harga beras, ditolaka. Artinya harga jagung tidak berpengaruh pada harga beras.

Tabel 3. Hasil Analisis Faktor-faktor yang Mempengaruhi Ketersediaan Beras Nasional

\begin{tabular}{|c|c|c|c|c|c|c|}
\hline \multirow{2}{*}{ Variabel } & \multicolumn{6}{|c|}{ Koefisien Regresi } \\
\hline & \multicolumn{2}{|l|}{ 1979-1997 } & \multicolumn{2}{|l|}{$1997-2008$} & \multicolumn{2}{|l|}{ 1978-2008 } \\
\hline \multirow{2}{*}{ Konstanta } & $-11,23017$ & & 0,013303 & & 0,010864 & \\
\hline & $-1,260800$ & & 1,401713 & & 1,591898 & \\
\hline \multirow{2}{*}{$\begin{array}{l}\text { In Pengadaan Dalam } \\
\text { Negeri (PD) }\end{array}$} & 0,004196 & ts & 0,030841 & * & 0,015112 & * \\
\hline & 0,250311 & & 2,056722 & & 1,840091 & \\
\hline \multirow{2}{*}{$\begin{array}{l}\text { In Nilai Tukar Petani } \\
\text { (NTP) }\end{array}$} & 0,173461 & ts & 0,565159 & $* * *$ & 0,341956 & $* * *$ \\
\hline & 0.623097 & & 3,461121 & & 2,868182 & \\
\hline \multirow{2}{*}{$\begin{array}{l}\text { In Konsumsi per Kapita } \\
\text { (KK) }\end{array}$} & $-0,139614$ & ts & $-0,135505$ & ts & $-1,165604$ & ts \\
\hline & $-0,771696$ & & $-0,738851$ & & 0,44524 & \\
\hline \multirow{2}{*}{ In Luas Panen (LP) } & 1,701880 & $* *$ & 1,246944 & $* * *$ & 1,160194 & $* * *$ \\
\hline & 3,354209 & & 4,983379 & & 5,589852 & \\
\hline \multirow{2}{*}{$\begin{array}{l}\text { In Rasio Harga } \\
(\mathrm{RH})\end{array}$} & $-0,003550$ & ts & $-0,033872$ & ts & 0,020360 & ts \\
\hline & $-0,141885$ & & $-0,777197$ & & 0,783604 & \\
\hline \multirow{2}{*}{ Dummy } & - & & - & & $-0,080035$ & $* *$ \\
\hline & - & & - & & $-2,388716$ & \\
\hline $\mathrm{R}^{2}$ & 0,833234 & & 0,771022 & & 0,740308 & \\
\hline Adjusted $\mathrm{R}^{2}$ & 0,694263 & & 0,675614 & & 0,669483 & \\
\hline $\mathrm{F}(\mathrm{p})$ & 5,995729 & & 8,081340 & & 10,45262 & \\
\hline $\mathrm{D}-\mathrm{W}$ & 2,012953 & & 1,667845 & & 2,030147 & \\
\hline
\end{tabular}

Sumber : Analisis data sekunder tahun 1979-2008

Catatan:

$* * *=$ signifikan pada tingkat kepercayaan $1 \%$

** = signifikan pada tingkat kepercayaan 5\%

* = signifikan pada tingkat kepercayaan $10 \%$

ts = tidak sigbifikan

Angka cetak miring adalah nilai t-terhitung 
Impor beras (IB), memiliki koefisien regresi sebesar 0,012715 dengan t-terhitung $1,373829(\mathrm{p}=0,1833>0,10)$. Membandingkan nilai t-terhitung dengan $\mathrm{t}$ tabel pada $\mathrm{df}(\mathrm{n}-1)=$ 29 dan $\alpha=0,10$; yaitu 1,669 , maka t-terhitung $<$ t-tabel. Dengan demikian, hipotesis $\mathrm{H}_{0}$ yang menyatakan tidak ada pengaruh impor beras pada harga beras, diterima dan Ha yang menyatakan ada pengaruh impor beras pada harga beras, ditolak. Artinya impor beras tidak berpengaruh pada harga beras.

\section{Hasil analisis faktor-faktor yang mempengaruhi ketersediaan beras di tingkat nasional}

Pada Tabel 3. menunjukkan hasil analisis regresi Ordinary Least Square (OLS) ketersediaan beras. Dalam penelitian ini diamati faktor-faktor yang mempengaruhi terhadap ketersediaan beras di tingkat nasional selama 30 tahun terakhir (1979-2009) dengan membandingkan periode sebelum krisis (19791997) dan sesudah krisis (1998-2009) sebagai dummy.

Nilai $\mathrm{R}^{2}$ pada model ketersediaan beras sebesar 0,740308 yang menunjukkan bahwa kontribusi pengaruh variabel-variabel bebas pada terikat adalah sebesar $74,03 \%$. Nilai $F$ 10.45262 dengan probabilitas $0.000016<0,05$, menunjukkan secara bersama-sama variabel bebas memberikan pengaruh pada variabel terikat. Nilai D-W 2.030147 ada pada daerah dL $(0,926)$ sampai dU $(2,034)$. Daerah di mana gejala autokorelasi tidak dapat diputuskan.

Hasil pada model ketersediaan beras secara nasional dari tahun 1979-2008 menunjukkan bahwa dari enam variabel bebas (pengadaan dalam negeri, indeks nilai tukar petani, tingkat konsumsi per kapita, luas panen padi, rasio harga dan dummy), empat diantaranya (pengadaan dalam negeri, nilai tukar petani, luas panen, dan dummy) ditemukan berpengaruh signifikan pada ketersediaan beras domestik. Hasil-hasil analisis pada model ketersediaan beras dijelaskan sebagai berikut:

Pengadaan dalam negeri (PD), memiliki koefisien regresi sebesar 0,015112 dengan t-terhitung 1,840091 ( $\mathrm{p}=0.0793<0,1)$. Membandingkan nilai t-terhitung dengan $\mathrm{t}$ tabel pada df $(\mathrm{n}-1)=29$ dan $\alpha=0,1$; yaitu 1,699 , maka t-terhitung $>$ t-tabel. Dengan demikian, hipotesis $\mathrm{H}_{0}$ yang menyatakan tidak ada pengaruh pengadaan dalam negeri pada ketersediaan beras, ditolak dan $\mathrm{Ha}$ yang menyatakan ada pengaruh pengadaan dalam negeri pada ketersediaan beras, diterima. Hal ini menyatakan bahwa PD berpengaruh pada ketersediaan beras. Peningkatan pengadaan dalam negeri sebesar $1 \%$ akan meningkatkan ketersediaan beras di tingkat nasional sebesar $0,02 \%$ apabila variabel lain tetap.

Indeks nilai tukar petani (NTP), memiliki koefisien regresi sebesar 0.341956 dengan t-terhitung 2,868182 ( $\mathrm{p}=0.0089<$ $0,01)$. Membandingkan nilai t-terhitung dengan $\mathrm{t}$ tabel pada df $(\mathrm{n}-1)=29$ dan $\alpha=0,01$; yaitu 2,756 maka t-terhitung $>$ t-tabel. Dengan demikian, hipotesis $\mathrm{H}_{0}$ yang menyatakan tidak ada pengaruh indeks nilai tukar petani pada ketersediaan beras, ditolak dan $\mathrm{Ha}$ yang menyatakan ada pengaruh indeks nilai tukar petani pada ketersediaan beras, diterima. Hal ini menyatakan bahwa nilai tukar petani berpengaruh pada ketersediaan beras.Peningkatan nilai tukar petani sebesar $1 \%$ akan meningkatkan ketersediaan beras di tingkat nasional sebesar $0,34 \%$ apabila variabel lain tetap.

Konsumsi per kapita (KK), memiliki koefisien regresi sebesar -0.115760 dengan tterhitung $-1,165604(\mathrm{p}=0.2563>0,10)$. Membandingkan nilai t-terhitung dengan $\mathrm{t}$ tabel pada df $(n-1)=29$ dan $\alpha=0,10$; yaitu 1,699 , maka t-terhitung $<\mathrm{t}$-tabel. Dengan demikian, hipotesis $\mathrm{H}_{0}$ yang menyatakan tidak ada pengaruh konsumsi per kapita pada ketersediaan beras, diterima dan $\mathrm{Ha}$ yang menyatakan ada pengaruh konsumsi per kapita pada ketersediaan beras, ditolak. Hal ini menyatakan bahwa konsumsi per kapita tidak berpengaruh pada ketersediaan beras di tingkat nasional.

Luas panen padi (LP), memiliki koefisien regresi sebesar 1,160194 dengan t-terhitung 5,589852 ( $\mathrm{p}=0.0000<0,01)$. Membandingkan nilai t-terhitung dengan $\mathrm{t}$ tabel pada df $(n-1)=29$ dan $\alpha=0,01$; yaitu 2,756 , maka t-terhitung $>$ t-tabel. Dengan demikian, hipotesis $\mathrm{H}_{0}$ yang menyatakan tidak ada pengaruh luas panen padi pada ketersediaan beras, ditolak dan $\mathrm{Ha}$ yang menyatakan ada pengaruh luas panen padi pada ketersediaan beras, diterima. Hal ini menyatakan bahwa LP 
berpengaruh pada ketersediaan beras. Dengan demikian, setiap kenaikan $1 \%$ pada luas panen padi akan meningkatkan ketersediaan beras di tingkat nasional sebesar $1,16 \%$ apabila variabel lain tetap.

Rasio harga (RH), memiliki koefisien regresi sebesar 0,020360 dengan t-terhitung $0,783604(p=0,4416<0,1)$. Membandingkan nilai $\mathrm{t}$-terhitung dengan $\mathrm{t}$ tabel pada $\mathrm{df}(\mathrm{n}-1)=$ 29 dan $\alpha=0,1$; yaitu 1,699 , maka t-terhitung $<$ t-tabel. Dengan demikian, hipotesis $\mathrm{H}_{0}$ yang menyatakan tidak ada pengaruh rasio harga pada ketersediaan beras, diterima dan $\mathrm{Ha}$ yang menyatakan ada pengaruh rasio harga pada ketersediaan beras, ditolak. Hal ini menyatakan bahwa RH tidak berpengaruh pada ketersediaan beras di tingkat nasional.

Saat sebelum dan sesudah krisis (dummy), memiliki koefisien regresi sebesar $-0,080035$ dengan t-terhitung $-2,388716(\mathrm{p}=$ $0,0259<0,05)$. Membandingkan nilai $\mathrm{t}$-terhitung dengan $\mathrm{t}$ tabel pada $\mathrm{df}(\mathrm{n}-1)=29$ dan $\alpha=0,05$; yaitu 2,045, maka t-terhitung $>\mathrm{t}$ tabel. Dengan demikian, hipotesis $\mathrm{H}_{0}$ yang menyatakan tidak ada pengaruh saat sebelum dan sesudah krisis pada ketersediaan beras, ditolak dan Ha yang menyatakan ada pengaruh saat sebelum dan sesudah krisis pada ketersediaan beras, diterima. Hal ini menyatakan bahwa saat sebelum dan sesudah krisis berpengaruh pada ketersediaan beras. Dengan demikian, melihat koefisien sebesar 0,080035 menunjukkan di tingkat nasional pada saat sebelum krisis memiliki ketersediaan beras lebih besar dari pada setelah krisis sebesar $0,08 \%$.

Nilai $\mathrm{R}^{2}$ pada model 1979-1997 sebesar 0,771022 yang menunjukkan bahwa kontribusi pengaruh variabel-variabel bebas pada terikat adalah sebesar $77,10 \%$. Nilai F 8,081340 dengan probabilitas $0,001524<0,05$, menunjukkan secara bersama-sama variabel bebas memberikan pengaruh pada variabel terikat. Nilai D-W 1,667845 ada pada daerah dL $(0,649)$ sampai dU $(2,206)$. Daerah di mana gejala autokorelasi tidak dapat diputuskan. Pada model 1997-2008, nilai $\mathrm{R}^{2}$ sebesar 0,833234 yang menunjukkan bahwa kontribusi pengaruh variabel-variabel bebas pada terikat adalah sebesar 83,32\%. Nilai F 5,995729 dengan probabilitas $0,024921<0,05$, menunjukkan secara bersama-sama variabel bebas memberikan pengaruh pada variabel terikat. Nilai D-W 2,012953 ada pada daerah 4dU $(0,995)$ sampai dU $(3,005)$. Daerah di mana tidak ada gejala autokorelasi.

Hasil pada model 1979-1997 dan model 1997-2008 dapat diuraikan sebagai berikut:

Pengadaan dalam negeri (PD) pada saat sebelum krisis ditemukan signifikan pada level tingkat kesalahan $10 \%$ sedangkan pada saat sesudah krisis tidak ditemukan signifikan. Koefisien regresi PD saat sebelum krisis 0,030841 menunjukkan bahwa pengaruh PD pada ketersediaan beras adalah positif. Hal ini menyatakan bahwa peningkatan $1 \%$ pada pengadaan dalam negeri akan meningkatkan ketersediaan beras di tingkat nasional sebesar $0,03 \%$ dengan asumsi variabel lainnya tetap.

Indeks nilai tukar petani (NTP) sebelum krisis tidak berpengaruh signifikan pada tingkat kesalahan $1 \%$ sedangkan pada saat sesudah krisis signifikan. Koefisien regresi NTP saat sesudah krisis 0,565159 menunjukkan bahwa pengaruh NTP pada ketersediaan beras adalah positif. Hal ini menunjukkan bahwa peningkatan nilai tukar petani sebesar 1\% akan meningkatkan ketersediaan beras di tingkat nasional sebesar $0,57 \%$ dengan asumsi variabel lainnya tetap. Dengan kata lain, semakin tinggi nilai tukar petani yang juga menandakan petani relatif lebih sejahtera akan berdampak pada meningkatnya produksi padi sehingga ketersediaan beras melimpah, dan supply yang melimpah.

Konsumsi per kapita (KK), pada saat sebelum dan sesudah krisis ditemukan tidak berpengaruh pada ketersediaan beras. Koefisien regresi KK pada saat sebelum dan sesudah krisis masing-masing $-0,135505$ dan $-0,139614$, dengan t-terhitung masing-masing

$0,738851(\mathrm{p}=0.4742>0,10)$ dan $-0,139614(\mathrm{p}$ $=0.4742>0,10)$. Membandingkan nilai $\mathrm{t}-$ terhitung dengan $\mathrm{t}$ tabel pada $\mathrm{df}(\mathrm{n}-1)=17$ dan $\alpha=0,10$; yaitu 1,740 , maka t-terhitung $<\mathrm{t}$ tabel pada saat sebelum krisis dan terhitung dengan $\mathrm{t}$ tabel pada df $(\mathrm{n}-1)=13$ dan $\alpha=0,10$; yaitu 1,771 , maka t-terhitung $<\mathrm{t}$-tabel pada saat sesudah krisis. Dengan demikian, baik pada saat sebelum krisis dan sesudah krisis, hipotesis $\mathrm{H}_{0}$ yang menyatakan tidak ada pengaruh saat sebelum dan sesudah krisis pada ketersediaan beras, diterima dan Ha yang menyatakan ada 
pengaruh saat sebelum dan sesudah krisis pada ketersediaan beras, ditolak Hal ini menyatakan bahwa KK pada saat sebelum dan sesudah krisis tidak berpengaruh pada ketersediaan beras di tingkat nasional.

Luas panen padi (LP), pada saat sebelum krisis ditemukan berpengaruh pada ketersediaan beras pada tingkat kepercayaan $1 \%$, sedangkan pada saat sesudah krisis ditemukan tidak signifikan terhadap ketersediaan beras. Koefisien regresi LP saat sebelum krisis 1,246944 menunjukkan pengaruh luas panen padi pada ketersediaan beras adalah positif. Hal ini menyatakan bahwa peningkatan $1 \%$ pada luas panen padi akan menyebabkan peningkatan sebesar $1,25 \%$ pada ketersediaan beras di tingkat nasional dengan asumsi variabel lain tetap. Sesudah krisis, luas panen padi tidak berpengaruh terhadap ketersediaan beras di tingkat nasional..

Rasio harga (RH), pada saat sebelum dan sesudah krisis ditemukan tidak berpengaruh pada ketersediaan beras. Koefisien regresi RH pada saat sebelum dan sesudah krisis masing-masing $-0,033872$ dan $-0,003550$, dengan t-terhitung masing-masing $0,777197(\mathrm{p}=0,521>0,10)$ dan $-0,141885$ ( $\mathrm{p}$ $=0.8918>0,10)$. Membandingkan nilai $\mathrm{t}$ terhitung dengan $\mathrm{t}$ tabel pada $\mathrm{df}(\mathrm{n}-1)=17$ dan $\alpha=0,10$; yaitu 1,740 , maka t-terhitung $<\mathrm{t}$ tabel pada saat sebelum krisis dan terhitung dengan $t$ tabel pada df $(n-1)=13$ dan $\alpha=0,10$; yaitu 1,771, maka t-terhitung $<\mathrm{t}$-tabel pada saat sesudah krisis. Dengan demikian, baik pada saat sebelum krisis dan sesudah krisis, hipotesis
$\mathrm{H}_{0}$ yang menyatakan tidak ada pengaruh saat sebelum dan sesudah krisis pada ketersediaan beras, diterima dan Ha yang menyatakan ada pengaruh saat sebelum dan sesudah krisis pada ketersediaan beras, ditolak Hal ini menyatakan bahwa RH pada saat sebelum dan sesudah krisis tidak berpengaruh pada ketersediaan beras di tingkat nasional.

\section{Implikasi Hasil Penelitian dan Kebijakan}

Secara keseluruhan dapat diketahui bahwa ketersediaan beras di tingkat nasional setelah krisis meningkat secara signifikan, terutama pada produksi dalam negeri. Laju produksi dalam negeri yang signifikan ini berdampak pada menurunnya impor beras dan meningkatnya kesejahteraan rumahtangga petani. Berdasarkan pengaruh masing-masing faktor penentu ketersediaan beras nasional tersebut dapat diperhitungkan tingkat kontribusi faktor-faktor tersebut terhadap pertumbuhan ketersediaan beras nasional seperti disajikan pada Tabel 4.4. Secara jangka panjang paling besar kontribusi terhadap pertumbuhan ketersediaan beras adalah pada indikator produksi $(20,768 \%)$ lalu kesejahteraan $(11,92 \%)$ dan permintaan $(9,93 \%)$.

Permintaan akan konsumsi beras pada saat sebelum krisis memberikan kontribusi sebesar $18,34 \%$ namun pada saat sesudah krisis menurun menjadi $18,09 \%$. Meskipun demikian ada peningkatan kesejahteraan rumahtangga petani dari sebelum krisis sebesar 16,33\% menjadi $27,84 \%$ pada saat sesudah krisis.

Tabel 4. Kontribusi Indikator Pertumbuhan Ketersediaan Beras, 1979-2008.

\begin{tabular}{llrrr} 
& & \multicolumn{2}{c}{ Kontribusi terhadap Pertumbuhan (\%) } \\
\cline { 3 - 5 } \multicolumn{1}{c}{ Variabel } & & $1979-1997$ & $1997-2008$ & $1979-2008$ \\
& & 1,49 & 1,68 & 0,82 \\
& & 16,33 & 27,84 & 11,92 \\
Pengadaan Dalam Negeri & Stok Nasional & 18,34 & 18,09 & 9,93 \\
Indeks Nilai Tukar Petani & Kesejahteraan & 25,02 & 50,74 & 20,76 \\
Konsumsi/Kapita & Permintaan & 4,36 & 2,50 & 2,59 \\
Luas Panen Padi & Produksi & - & - & 3,35 \\
Rasio Harga & Impor & & & \\
Dummy Setelah Krisis & Ekonomi Nasional & & &
\end{tabular}

Sumber: Analisis data sekunder, BPS dan BULOG 
Hal ini karena adanya peningkatan produksi padi, di mana sebelum krisis dengan kontribusi $25,02 \%$ menjadi $50,74 \%$ pada sesudah krisis dan berdampak pada peningkatan stok beras secara nasional dari $1,49 \%$ sebelum krisis menjadi $1,68 \%$ serta menurunnya impor beras dari $4,36 \%$ pada saat sebelum krisis menjadi $2,50 \%$ pada saat sesudah krisis.

Tujuan pembangunan pertanian khususnya pada komoditas padi diantaranya adalah meningkatnya kesejahteraan petani. Hasil penelitian ini menunjukkan bahwa indicator kesejahteraan petani diantaranya adalah meningkatnya indeks Nilai Tukar petani (NTP). Variabel penting yang mempengaruhi peningkatan indeks NTP adalah luas panen dan stabilitas harga gabah/beras. Dipandang penting pemerintah menjamin agar luas panen (lahan pertanian, khususnya untuk komoditas tanaman padi) dipertahankan dan diintensifikasikan agar produksi semakin melimpah sehingga akan meningkatkan ketersediaan beras secara nasional dan mengurangi impor. Untuk itu, diperlukan kebijakan strategis lain agar petani semakin bergairah dalam usaha petanian tanaman padi ini dengan menjamin stabilisasi harga gabah/beras yang mampu menyesuaikan dengan daya beli petani untuk harga-harga lain selain beras.

\section{KESIMPULAN}

1. Laju perkembangan harga beras eceran di tingkat nasional mengalami kecenderungan meningkat secara positif.

2. Harga beras domestik di tingkat nasional dipengaruhi oleh harga dasar gabah dan harga beras dunia

3. Ketersediaan beras jangka panjang di tingkat nasional dari tahun 1979-2008 dipengaruhi oleh pengadaan dalam negeri, nilai tukar petani, dan luas panen serta ketersediaan beras sebelum dan sesudah krisis. Ketersediaan beras jangka pendek sebelum dan setelah krisis dipengaruhi secara berbeda oleh faktor-faktor penentu yang ditetapkan. Pada saat sebelum krisis (1979-1997), luas panen mempengaruhi secara signifikan dan pada saat sesudah krisis (1997-2008), pengadaan dalam negeri, nilai tukar petani, dan luas panen mempengaruhi secara signifikan .

\section{DAFTAR PUSTAKA}

Anonim. 2001. Pengolahan Data Statistik dengan SPSS 10.0, Salemba Infotek dan Wahana Komputer, Jakarta.

Darwanto, D.H., 2005, Ketahanan Pangan Berbasis Produksi dan Kesejahteraan Petani, Jurnal Ilmu Pertanian, 12 (2), hal. 152-164.

Kompas, 2003, Indonesia Masih Pengimpor Beras Terbesar, 25 Januari 2003.

Pranadji, T., 2003, Reformasi Kelembagaan untuk Kemandirian Perekonomian Pedesaan, Paper dalam Workshop Metodologi Penelitian Kelembagaan, 2527 Februari 2003. Publishing Jurusan Sosial Ekonomi. Fakultas Pertanian Bogor.

Rachman, H.P.S., 2005. Metode Analisis Harga Pangan, dalam Makalah yang disampaikan pada Apresiasi "Sistem Distribusi Pangan dan Harga Pangan" yang diselenggarakan oleh Badan Ketahanan Pangan, Departemen Pertanian, di Pusat Manajemen Pengembangan SDM Pertanian, Ciawi, Bogor, 3-5 Juli.

Sawit, M.H.. 2000, Arah kebijaksanaan distribusi/perdagangan beras dalam mendukung ketahanan pangan: perdagangan dalam negeri. Dalam Pertanian dan Pangan: Bunga Ram-pai Pemikiran Menuju Ketahanan Pangan (Eds. R. Wibowo), pp 222-242. Pustaka Sinar Harapan, Jakarta.

Widarjono, A., 2009, Ekonometrika, Pengantar dan Aplikasinya (Cetakan Ketiga), Penerbit Ekonesia, Yogyakarta. 